\title{
SINCRETISMO NA FIGURATIVIZAÇÃO DA AULA DE INGLÊS: ANÁLISE DE UM LIVRO DIDÁTICO
}

\author{
SYNCRETISM IN FIGURATIVIZATION OF ENGLISH CLASS: \\ A TEXTBOOK ANALYSIS
}

\author{
Raquel Salcedo Gomes \\ UNISINOS - Universidade do Vale do Rio dos Sinos ${ }^{1}$ \\ Marcelo Salcedo Gomes \\ UNISINOS - Universidade do Vale do Rio dos Sinos ${ }^{2}$
}

\begin{abstract}
RESUMO: Este artigo objetiva uma investigação sobre os efeitos de sentido resultantes do emprego de linguagem sincrética verbo-visual em um livro didático de língua estrangeira, distribuído pelo Plano Nacional do Livro Didático para escolas públicas de todo o país. Centralizamos a análise nos papéis do professor e dos alunos figurativizados na prática semiótica aula e em como essa figurativização é afetada pela midiatização da sociedade. Para tanto, selecionamos a primeira unidade do volume elaborado para o sexto ano do Ensino Fundamental, analisando-a a partir dos conceitos de linguagem sincrética de L. Hjelmslev (1975) e na semiótica das práticas de J. Fontanille (2005). A análise indicou que a aula de inglês enquanto prática semiótica é concebida como espaço de interação e da presença de temáticas emergentes na sociedade contemporânea. Porém, apesar de todo este revestimento de atualidade, ainda está centrada nas figuras do professor e do livro didático como sujeitos do saber, ao passo que o aluno, apesar de respeitado em seus saberes e mais livre para efetuar escolhas, ainda é representado como receptor do conhecimento.
\end{abstract}

PALAVRAS-CHAVE: linguagem sincrética; figurativização; livro didático; aula de inglês; práticas semióticas; midiatização.

ABSTRACT: This article aims at researching on the effects of meaning resulting from the use of syncretic verb-visual language in a foreign language textbook distributed by the National Textbook Plan for public schools across the country. We have centralized the analysis on the roles of teacher and students figurativized in the semiotic practice of class and how it is affected by the mediatization of society. To this end, we have selected the first unit of the volume prepared for the sixth grade of elementary school, analyzing it from the notions of syncretic language by L. Hjelmslev (1975) and semiotics of practices by J. Fontanille (2005). The analysis demonstrated that the English class as a social practice is conceived as a space for interaction and presence of emerging themes in contemporary society. However, despite all this coating of freshness, it is still centered in the figures

\footnotetext{
${ }^{1}$ Doutoranda no Programa de Pós-graduação em Linguística Aplicada na Universidade do Vale do Rio dos Sinos. Mestre em Linguística Aplicada pela mesma instituição. Tradutora Pública (juramentada) pela Junta Comercial do Rio Grande do Sul, professora da Rede Municipal de Educação de Novo Hamburgo, atuando como docente de língua inglesa nas séries finais do Ensino Fundamental e tutora EAD do Curso de Extensão em Produção de Material Didático para a Diversidade, pela Universidade Federal do Rio Grande do Sul. Atualmente, também colunista de educação para o Jornal da Lombra Grande, no município de Novo Hamburgo ${ }^{2}$ Doutorando em Ciências da Comunicação.
} 
of the teacher and the textbook as subjects of knowledge, whereas the student, although respected in his knowledge and freer to make choices, is still represented as its receiver.

KEYWORDS: syncretic language; figurativization; textbook; english class; semiotic practices; mediatization.

\section{INTRODUÇÃO}

O objetivo desse artigo é investigar que tipo de sentido a linguagem sincrética verbo-visual produz em um material didático de língua estrangeira/adicional ${ }^{3}$ no que diz respeito ao papel de professor e alunos figurativizados na prática social aula e como isso está sendo afetado pela sociedade midiatizada. ${ }^{4} \mathrm{O}$ livro em análise intitula-se Links - English for teens. Publicado pela editora Ática em 2009, compõe a lista de livros didáticos aprovados para o Programa Nacional do Livro Didático (PNLD) do Ministério da Educação, para os anos de 2011, 2012 e 2013.

De acordo com o PNLD, o livro em estudo é um material consumível, podendo o aluno nele escrever e levá-lo para casa ao final do ano letivo. A série também é adotada por escolas da rede particular de ensino. Os autores, Amadeu Marques e Denise Santos, são especialistas, escritores de uma extensa lista de materiais didáticos e paradidáticos para o ensino da língua inglesa, ambos nesta função há mais de vinte e cinco anos.

A teorização sobre sincretismo de linguagens foi concebida primeiramente por L. Hjelmslev em seus Prolegômenos a uma Teoria da Linguagem, em 1943. Estudos posteriores em semiótica levaram essa concepção adiante e, com base na teoria Semiótica das Práticas (FONTANILLE, 2008), analisamos a capa e a primeira unidade do livro desenvolvido para o $6^{\circ}$ ano do Ensino Fundamental de nove anos. Tal escolha justifica-se por ser o primeiro contato formal do estudante de escola pública com material didático de língua estrangeira, de modo que se pode investigar como a linguagem da obra é construída a fim de estimular, no estudante, o desejo de aprender o idioma.

$\mathrm{Na}$ seção a seguir, discorremos a respeito da prática semiótica aula e sua figurativização no livro didático, cuja análise, enquanto texto sincrético, é viabilizada pelo aporte teórico da Semiótica Discursiva, mais especificamente a Semiótica das Práticas. Em seguida, descrevemos a capa e discutimos seus principais elementos, que constituem a narrativa que dirige o funcionamento do livro. Na terceira seção, apresentamos o conteúdo da primeira unidade do livro, mostrando seu alinhamento à narrativa preconizada na capa. Por fim, trazemos nossas considerações elencadas e constatadas a partir da análise empreendida.

\section{A AULA ENQUANTO PRÁtica SEMIÓTICA}

A aula de língua estrangeira, como toda aula, é uma prática semiótica que, de acordo com a Semiótica das Práticas de Jacques Fontanille (2008), insere-se dentro de uma cena semiótica que, por sua vez, insere-se em uma estratégia pertencente a uma forma de vida. Ou seja, as pessoas são seres que agem no mundo dentro de variadas configurações culturais, denominadas pelo semioticista francês de formas de vida (FONTANILLE, 2008).

\footnotetext{
${ }^{3} \mathrm{O}$ termo "língua estrangeira" vem sendo, paulatinamente, substituído por "língua adicional" nos meios acadêmicos que pesquisam sobre o ensino/aprendizagem de línguas, a partir da compreensão que, desde o momento em que me aproprio de outra língua, ela deixa de ser estrangeira e passa a ser também minha, não minha língua materna, mas uma segunda língua, ou "adicional".

${ }^{4}$ Sobre midiatização, consultar Ferreira (2007).
} 
A teoria semiótica discursiva de linha francesa, à qual a semiótica das práticas se filia, foi elaborada para explicar os processos de formação de sentidos nos textos verbais. No decorrer do desenvolvimento da teoria, no entanto, o estatuto da imanência do sentido foi questionado (FONTANILLE, 2005), e houve o reforço do conceito de texto proposto no Dicionário de Semiótica (GREIMAS; COURTÉS, 1979), de modo que a definição de texto ampliou-se ao ponto de abranger tudo o que pode produzir sentido.

É neste aspecto da teoria que práticas podem ser concebidas como texto. Nesse processo, o texto deixa de ser tecido apenas pela linguagem verbal e passa a compor-se por diversas linguagens concomitantes, denominadas de linguagem sincrética. Texto ou a unidade de sentido passa a ser essas linguagens produzindo sentido como uma totalidade. Assim, a aula é um "texto" porque pretende fazer sentido para os que dela participam. Enquanto prática social em uma situação semiótica, ela é uma configuração heterogênea cujos elementos são capazes de produzir significação a partir dessa interação comunicativa.

Buscamos compreender, pela linguagem, esferas sociais que vão além dela própria. No caso do presente artigo, buscamos explicitar elementos da educação regular básica no Brasil, procurando analisar como o livro didático, fazendo uso de linguagem sincrética, constrói a cena predicativa aula, com seus actantes e processos.

Enquanto cena predicativa e objeto de estudo deste artigo, através de uma teoria semiótica, a aula, figurativizada no livro didático, gera significações, pretende trazer novas informações e mudanças ao conhecimento e às visões de mundo de seus participantes, isto é, seu objetivo é o de produzir semioses múltiplas.

Embora habilitada com todo esse capital simbólico, no sentido bourdieuano do termo, ou talvez, até mesmo por causa dele, diz-se que a aula e, mais ainda, a escola estão em crise. A crise na escola e a necessidade de seu fim na configuração atual foi anunciada pelo pensador vienense Ivan Illich, em seu livro Sociedade sem escolas, publicado no Brasil em 1977. Além dele, diversos artigos acadêmicos discorrem sobre a crise na escola, seus sintomas e causas. ${ }^{5}$

Com relação à aula enquanto prática, além das crenças relativas à necessidade de "vencer" conteúdos, sua principal crise diz respeito à desigualdade de poder que há entre os atores envolvidos: "professor" e "alunos". Sinclair e Coulthard (1975) estudaram a chamada sequência IRA (Iniciação-Resposta-Avaliação), tipo de interação que descobriram comum em aulas da escola regular: o professor inicia um questionamento que se refere a uma informação já ensinada ou a um conhecimento que já se sabe convencionado e estabelecido. Como reação do aluno se espera uma resposta pronta e, em troca, ele recebe um elogio ou avaliação positiva, que reforça a aceitação dessa atitude de sempre responder o que já é esperado.

No Brasil, o linguista aplicado Pedro Garcez (2006) desenvolveu estudos a partir das ideias de Sinclair e Coulthard (1975) em escolas locais e descobriu a preponderância do mesmo fenômeno: os alunos estão acostumados a responder o que se espera deles.

Essas colocações sobre possíveis crises no ambiente escolar não remetem a uma total ausência de ações visando à melhoria do sistema educacional. Pelo contrário, medidas são tomadas, nas várias instâncias da sociedade, como tentativa de superar os obstáculos à aprendizagem.

\footnotetext{
${ }^{5}$ Dentre esses, podemos citar: A escola pública no Brasil: problematizando a questão, de João Carlos da Silva, e Trabalho, estado e escola: crises que se entrecruzam, de Justino Souza Junior, ambos doutores em Educação.
}

Disponível em: http://seer.fclar.unesp.br/casa 
Dentre as ações de grande porte, pode-se incluir o Programa Nacional do Livro Didático, implementado no ano de 2011, que tem por objetivo fornecer material didático de qualidade às escolas públicas brasileiras.

\section{OS SENTIDOS NA CAPA DO LINKS}

Os livros da série são coloridos e ilustrados com fotografias e figuras dos personagens criados para a coleção. Os personagens principais são dois professores de língua inglesa, Greg Waters e Jane Baker. Ambos decidem vir morar no Brasil e lecionar o idioma em escolas do país. Além dos professores, seus respectivos alunos compõem os personagens da série, adicionando-se a eles o gato selvagem Jack Lynx. O nome do personagem felino faz um trocadilho com o título da coleção, uma vez que a palavra lynx, que significa "lince" em português, tem o mesmo som de Links, nome da série.

A capa do livro didático apresenta os temas transversais que perpassam as lições: educação, adolescência, tecnologia, liberdade e cultura. Esses temas são figurativizados na capa do volume para o $6^{\circ}$ ano, com fotos horizontalizadas de situações de aprendizagem e interação referentes ao idioma, buscando relacionar a língua inglesa com a dinamicidade de um mundo globalizado, tecnológico e midiatizado.

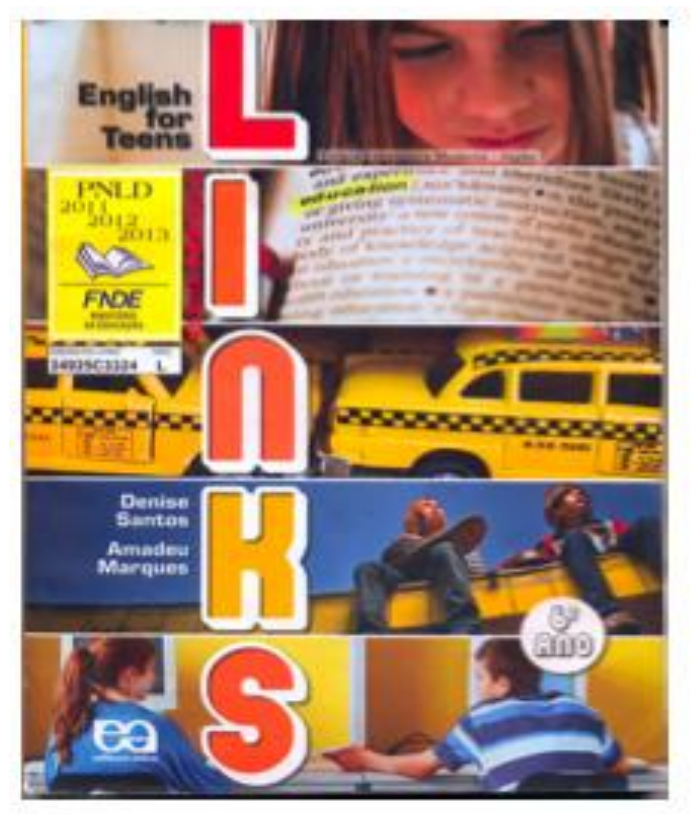

FIGURA 1 - Capa do livro Links para o $6^{\circ}$ ano

As letras do nome do livro estão na orientação vertical, uma letra em cada fotografia horizontalmente estendida, adicionando o sentido de cruzamento de linguagens, no caso a fotografia bidimensional e o signo verbal. Interessante observar que as letras possuem contraste com as cores das fotografias atrás, contornos e relevos, que lhe conferem características de imagem, reforçando o sincretismo. Como links, na língua inglesa, significa "ligações" ou "elos", a capa do livro ilustra essas ligações também na interseção de linguagens.

As fotos são recortadas, enfatizando aspectos específicos de uma cena. $\mathrm{Na}$ primeira foto, entrecruzada pela letra L, tem-se o foco no rosto de uma estudante adolescente 
que parece estar lendo com o olhar concentrado em um objeto que não se pode ver abaixo de si. O restante da foto está desfocado, o que destaca ainda mais o rosto e os cabelos esvoaçantes da jovem. Nessa interseção, lê-se ainda o subtítulo da série English for teens (inglês para adolescentes), o que reforça a qualidade "adolescente" da coleção.

A segunda foto, de cima para baixo da capa, traz a letra I com a palavra Education destacada em amarelo de uma página de dicionário em inglês. Identifica-se que a página é de um dicionário pela escrita fonética seguida ao termo, separada por barras e contendo os símbolos que representam a pronúncia. Após a escrita fonética há uma seta e a letra $\mathbf{n}$., que indica que a palavra é um noun, ou seja, um substantivo.

Essa foto também revela um sincretismo verbo-visual ao trazer a imagem do dicionário e o texto verbal em língua inglesa com a definição da palavra educação, fazendo autorreferência ao contexto formal de ensino/aprendizagem, em uma narrativa sobre as ações e instrumentos utilizados pelos usuários do livro e participantes da situação semiótica "aula".

A terceira fotografia da sequência, que traz, à sua frente, a letra $\mathrm{N}$, apresenta a imagem de dois táxis nova-iorquinos (New York cabs) como que enfileirados em um estacionamento repleto de táxis, com mais deles fora de foco na profundidade da foto. $\mathrm{O}$ observador mais atento notará que esses táxis são miniaturas metálicas, brinquedos infantis, reproduções dos automóveis reais.

As réplicas são de tão boa qualidade que trazem inclusive os dizeres nas laterais das portas: " $N$. Y. C. taxi" e um quadro na porta dianteira com os valores tarifários das corridas. Essa representação infantil de um objeto da realidade com forte apelo à cultura e a elementos relacionados à língua inglesa remete à caracterização do público para o qual o livro foi produzido: pré-adolescentes entre os onze e os treze anos de idade, pessoas saindo da infância, mas ainda estreitamente conectadas ao universo infantil.

Além disso, a ideia de simulacro, representação artificial do real elaborada por Baudrillard (1981) aparece aqui em múltiplas camadas, na plasticidade da foto, sua composição com os textos verbais fora dela no nome do livro e dentro dela nos dizeres das laterais das miniaturas e nessa ambiguidade de interpretações do objeto taxi fotografado, enquanto brinquedo, objeto relacionado à infância; enquanto carro, objeto do universo adulto (em uma dualidade tipicamente adolescente, entre os dois universos), atribuindo a tudo isso um caráter de qualificação do objeto como pertencente à cultura americana, de onde provém a disciplina em estudo no livro: a língua inglesa.

A fotografia em sequência na capa do livro refere-se à temática da liberdade, amplamente desejada dentro do universo adolescente. Temos, na superfície da capa, a letra K. Do lado esquerdo, podemos ler os nomes dos autores do livro e, do lado direito, em destaque, temos a figura de dois adolescentes de cabelos longos e soltos, na altura dos ombros, com skates em punho, olhando ao longe no horizonte, sentados, a céu aberto. Todos estes elementos remetem ao tema da liberdade e da contracultura, representada pelo esporte skate, símbolo de uma cultura esportiva desenvolvida pelos próprios jovens e popularizada nos anos de 1980.

A fotografia foi tirada em ângulo contra-plongée, isto é, de baixo para cima, engrandecendo os jovens fotografados, ampliando o céu acima de suas cabeças e presentificando o ideal de infinitude e liberdade do céu azul. Os adolescentes têm olhar sério e compenetrado, produzindo um efeito de rebeldia e protesto, considerados característicos da faixa etária.

A última fotografia, que traz à sua frente a letra $S$, mostra dois adolescentes, um menino e uma menina, sentados, de costas para quem olha a imagem e de frente para um monitor de computador. Vê-se o adolescente do sexo masculino entregando uma folha de 
papel para a jovem do sexo feminino. Ambos estão vestidos de azul com uma parede de cor amarela ao fundo. O contraste de cores, somado às formas retas dos monitores, produz um efeito da tecnologia como contemporaneidade, com as linhas retas, as cores e a aparência jovial dos atores fotografados. A imagem pode suscitar, nestes planos de expressão, no jovem leitor aprendiz, uma identificação, pelo colorido, pela atitude ativa da entrega do papel e da possível interação acontecendo entre os personagens.

Diferentemente do discurso puramente publicitário que visa persuadir seu leitor a uma ação (a compra), o discurso pedagógico caracteriza-se por ser um discurso de tipologia múltipla, com fundações político-científico-publicitárias que podem ser identificadas na capa em análise. Os temas construídos na capa como figuras, produzindo significações de liberdade, educação, adolescência, tecnologia e cultura interligam-se em uma tentativa de persuadir o leitor a um querer-saber que traz em si a expectativa auto-referencial da liberdade, do poder pelo saber, do saber como forma de poder.

A ação preconizada por este discurso é a de abrir o livro no intuito de querer aprender, o propósito é um fazer-querer-saber com a promessa de que esse saber terá como consequência um poder-fazer que abrirá portas para um futuro promissor. Aqui, o discurso pedagógico utiliza-se do interdiscurso do mundo social, do papel da escola, da importância do conhecimento de uma língua estrangeira para inserção no mercado de trabalho, das possibilidades de ascensão social, cultural e financeiras que o domínio de uma língua estrangeira podem proporcionar.

Nesse sentido, a análise da capa permite postular a presença de concepções que orientam as práticas semióticas e que repercutem na estrutura de poder dos discursos variados, dentre os quais o pedagógico. Este aspecto é importante para compreendermos os significados construídos no livro didático como texto.

O que a capa do livro didático proporciona com essa multiplicidade de figurativizações e tematizações é a persuasão do leitor a abrir o livro para estudar o idioma fazendo com que acredite que essas virtualidades temáticas tornar-se-ão concretas com a aprendizagem. A seguir, passamos à análise da Unidade 1 do livro Links para o $6^{\circ}$ ano do Ensino Fundamental.

\section{UNIDADE 1 - EFEITOS PRODUZIDOS A PARTIR DOS TEMAS}

Depois de abrir o livro, os leitores deparam-se com a unidade 1 ou Unit 1 . A unidade intitula-se: You know a lot of English (Você sabe bastante inglês). Tal título aproxima o estudante do objeto estudado, pressupondo que ele tem um conhecimento prévio da língua, adquirido em suas vivências em um mundo midiatizado e globalizado em que se está em contínuo contato com mídias (televisão, música, cinema, internet etc.) que abordam elementos da língua inglesa a todo momento.

Os temas da tecnologia e da sociedade globalizada e em vias de midiatização se fazem tão presentes no discurso do livro que, nas páginas 6 e 7, está a apresentação dos dois professores-personagens estrangeiros principais da série enquanto eles aparecem em suas escrivaninhas, acessando a internet, buscando, em sites de emprego, postos de trabalho como professores de inglês no Brasil.

A unidade inicia com a seção Let's read (Vamos ler), priorizando a habilidade de leitura na língua estrangeira, como sugerem os PCNs (1998). Abaixo do enunciado, está a afirmação Let's meet Jane and Greg (Vamos conhecer Jane e Greg), no intuito de apresentálos aos aprendizes leitores. 
CASA, Vol.11 n.1, julho de 2013

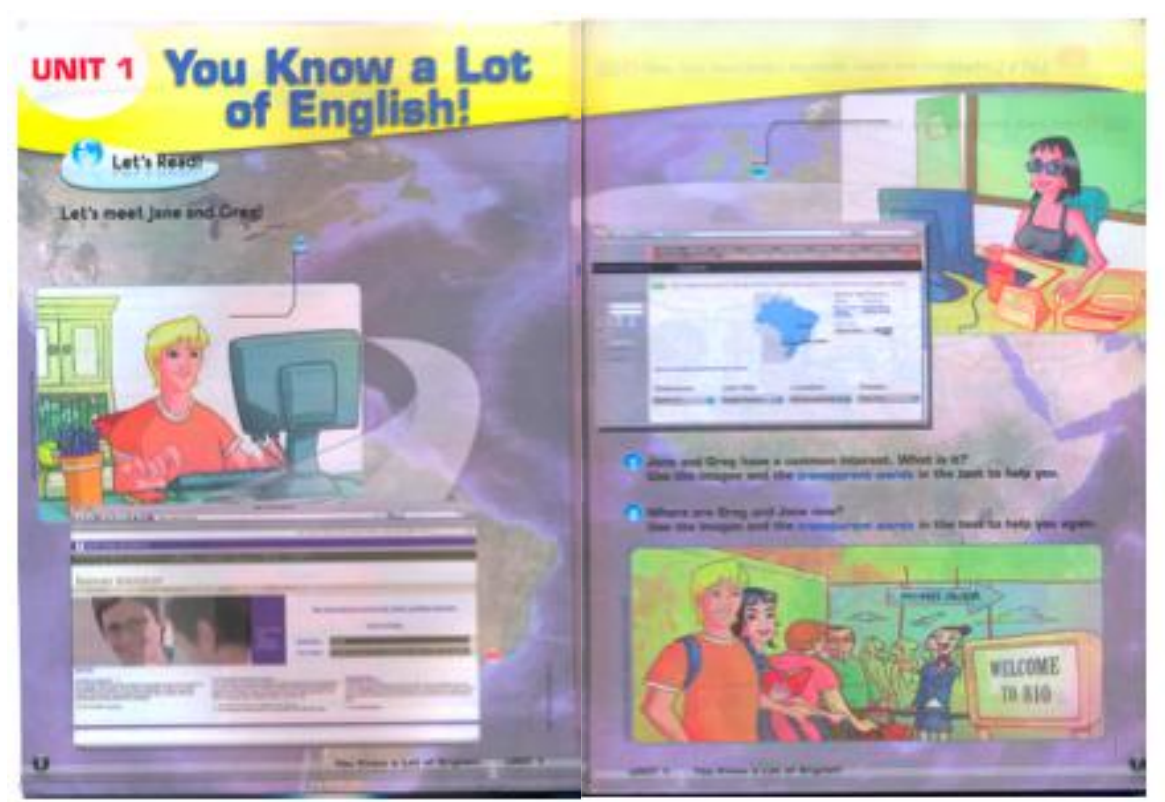

FIGURA 2 - Páginas 6 e 7

Sobrepostas às imagens dos professores, estão as páginas de internet de duas agências de recursos humanos, nas quais os personagens estão navegando na busca por seu emprego de professor no Brasil. Como pano de fundo dessas figuras, há um mapa-múndi em plano semitransparente, indicando com círculos em azul e linhas os locais de procedência dos dois professores, Greg, de Nova Iorque, nos Estados Unidos, e Jane, de Londres, na Inglaterra. Abaixo no mapa, com um círculo vermelho, está indicada a cidade do Rio de Janeiro, local para onde os dois irão trabalhar e viver.

$\mathrm{Na}$ parte inferior da página 7 , no final dessa sobreposição de imagens e informações, o livro traz duas questões. A primeira refere-se às imagens recém relatadas e pergunta qual é o interesse comum de Greg e Jane. A segunda refere-se à figura, abaixo na página, dos dois professores em uma fila de aeroporto, com malas, chegando ao Rio de Janeiro. A pergunta é Where are Greg and Jane now? (Onde estão Greg e Jane agora?), pretendendo indicar que chegaram ao Rio de Janeiro para atuar como professores.

Junto a essas questões, o livro pede que os alunos tentem encontrar as respostas usando as imagens e o que é chamado de transparent words (palavras transparentes). Essas são palavras similares na língua inglesa e portuguesa que os alunos podem utilizar como pistas para compreender o sentido de enunciados de uma língua para a outra. Por exemplo, os alunos podem inferir que passport é "passaporte" e que o local indicado é um aeroporto.

A estratégia de usar palavras transparentes ou dedutíveis de uma língua para a outra alinha-se com a ideia apresentada no título da unidade de que o estudante já sabe 
bastante inglês e pretende tornar o idioma familiar, ao demonstrar que muitas palavras são similares às de sua língua local.

O sincretismo verbo-visual destaca-se nessas duas páginas. Podem-se identificar quatro níveis de sobreposição de imagens: 1) o mapa ao fundo; 2) as figuras dos professores; 3) as imagens dos websites que estão acessando; 4) as fotografias e imagens no interior de cada website. Da mesma forma, os enunciados na linguagem verbal também se sobrepõem aos enunciados do livro sendo sobrepostos aos das imagens, sendo estes sobrepostos aos dos websites, dentro das imagens. A multiplicidade de informações e modos de expressão chama a atenção.

Aqui percebemos que os autores do livro procuram reproduzir, nas páginas impressas, um dos ambientes que mais atraem a juventude nos dias de hoje: a internet. São telas de computadores dispostas nas páginas, cuidadosamente desarrumadas, de modo a simular a abertura de "janelas" de diálogos da mesma forma que quando operamos um sistema informatizado. Além disso, os personagens estão representados em ilustrações, nas quais aparecem em frente a seus computadores, navegando na rede. De cada ilustração saem ligações gráficas que atingem o grande mapa-múndi (cada personagem em seu país de origem), que serve de pano de fundo para as páginas no melhor "estilo transparência" (recurso de muitos editores eletrônicos de imagem). Por fỉm, na última ilustração aparecem os personagens em um aeroporto no qual uma mensagem de boas-vindas é vista em um monitor grande. Se olharmos as duas páginas como unidade (Gestalt), perceberemos a semelhança com típicas páginas de websites, e todo o resto do contexto remete a uma "sociedade em rede" (CASTELLS, 2003) e globalizada.

Os professores, representantes do domínio da língua e suas possibilidades, são apresentados como pessoas jovens, contemporâneas, conectadas e viajadas. Ambos utilizam cortes de cabelos atuais e vestem-se com roupas e acessórios informais. O mundo da língua inglesa retratado pelo livro é um mundo de jovens, assim como o público a quem é destinado. A língua é apresentada como ferramenta para fazer coisas, como navegar na internet e viajar.

A próxima seção da unidade, na página 8, destina-se a apresentar os demais personagens da coleção, os alunos de Greg e Jane e prevê, para isso, atividades de listening (habilidade de escuta no idioma), leitura e escrita. O título da seção é Let's listen (Vamos escutar). Logo abaixo do título está o exercício 1, para ser feito junto com o CD, como indica um ícone com um fone de ouvido. A instrução do exercício diz: Let's meet Jane's students. Listen and point to the words you hear (Vamos conhecer os alunos de Jane. Ouça e aponte para as palavras que você ouvir).

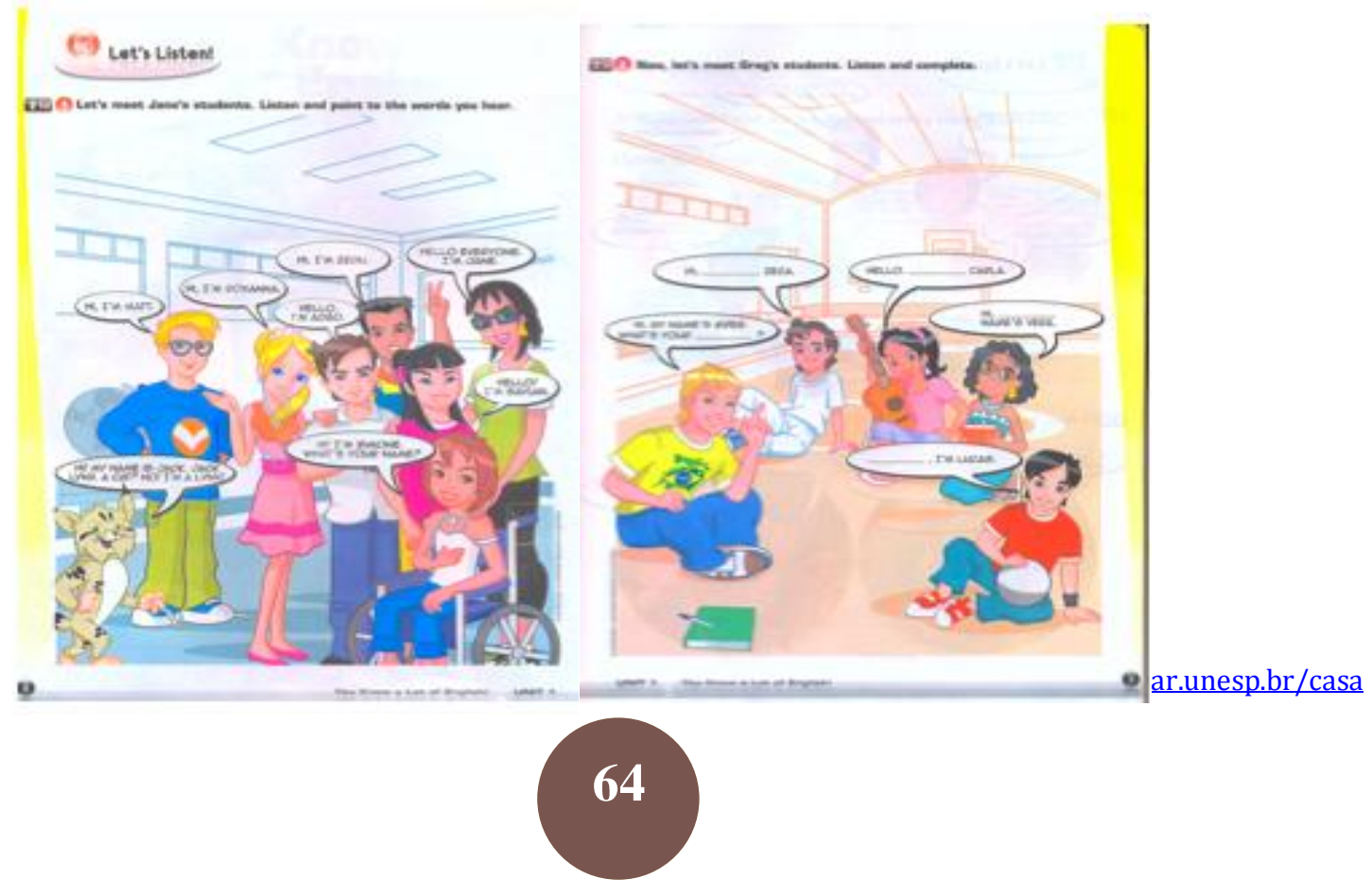




\section{FIGURA 3 - Páginas 8 e 9}

Atrás da instrução da atividade, está a figura de Jane e seus alunos, na sala de aula, como se estivessem pousando para uma fotografia. Cada personagem tem um balão de fala no qual está se apresentando na língua estrangeira. Jane possui seis alunos e, como atua em uma escola internacional, informação contida no site que consultou na página anterior, cada aluno tem uma nacionalidade diferente. Além dos alunos de Jane, aparece, ao pé da imagem, o personagem Jack Lynx, também se apresentado. Esse personagem é uma figurativização do próprio livro, pois é sempre ele quem dá dicas sobre a gramática e a estrutura do idioma, nas seções de reflexão sobre a língua.

É como se os demais personagens da narrativa pedagógica não pudessem falar sobre a gramática da língua, pois estão envolvidos em suas próprias interações. O papel de apresentar reflexões sobre a estrutura do idioma pertence ao personagem felino, que desempenha o papel de detentor do saber no percurso narrativo do livro. O próprio livro, enquanto repositório do saber sobre a língua, é figurativizado pelo simpático personagem lince, encarregado de explicar os conhecimentos linguísticos de forma lúdica e atraente, na busca pela superação da crença de que estudar língua é uma atividade entediante.

Na página 9, ao lado, a cena do professor posando na sala de aula com seus alunos se repete. Nesta página, encontra-se o exercício 2, também para ser feito com o CD. Neste exercício, além de ouvir as falas dos personagens, escritas em balões, o aluno deve completar essas falas com as partes que estão faltando, usando como modelo as falas da figura anterior e as informações que ouvir no CD. O professor Greg tem quatro alunos, brasileiros de uma comunidade da cidade do Rio de Janeiro.

Greg aparece na imagem com uma camiseta amarela com símbolos da bandeira brasileira. Ele e seus alunos estão sentados no chão, em um semicírculo, apresentando-se na língua inglesa. Aqui, as linguagens visual e verbal se hibridizam e, somando-se ao dinamismo das falas dos personagens com o áudio, a sensação de ação proporcionada pelos balões de fala e a própria ideia de movimento congelado das imagens, gera a impressão de que há uma ação ocorrendo na "tela" do livro, uma ação que ocorre para o aluno espectador, que interage com a narrativa enquanto aprende estruturas da língua.

O aluno é necessário para concretizar a narrativa, pois ele precisa preencher as falas para que se possa ler, mais do que ouvir, o que os personagens estão falando. Aqui também notamos a intervenção das tecnologias na complexificação do "dispositivo" (BRAGA, 2011) aula. A obrigatoriedade do uso do CD como recurso técnico remete os atores sociais a uma contemporaneidade que lhes é familiar, na medida em que lhes é oferecida a todo momento, seja pela música, jogos de videogame, programas de computador etc.

Na página 10, tem-se a seção Let's Speak (Vamos falar), com duas atividades. A primeira pede que os alunos ouçam e leiam uma série de figuras em círculos com os rostos de Jane e seus alunos dizendo suas nacionalidades em balões. Cada balão contém a frase I'm from... com a nacionalidade de cada indivíduo. Essa atividade visa à apresentação e prática da nova estrutura, ainda na situação comunicativa de apresentação. Além de dizer que é da Inglaterra, a professora Jane pergunta Where are you from? (De onde você é?), apresentando essa pergunta aos alunos e estimulando-os a responder, ou seja, à interação.

A segunda atividade da página 10 pede que os alunos leiam estruturas presentes nos balões. A atividade soma as frases apresentadas nas páginas 8 e 9 às da atividade anterior, mostrando diálogos. Percebemos que eles utilizam imagens de dois 
websites: Getty Images e Jupiter Images, mas não o representam com o URL de página, apenas citam o nome não remetendo o leitor para outra mídia.

Na página 11, tem-se a seção Grammar in Action, que apresenta aspectos relativos à gramática. Aqui há uma subnarrativa dentro da narrativa principal dos professores Greg e Jane e seus alunos: Simone, uma aluna da professora Jane que se locomove numa cadeira de rodas (referência à temática da inclusão) escreve e ilustra uma história em quadrinhos. Sua subnarrativa funciona como pano de fundo para a apresentação das formas contraídas de I am, what is e my name is. Essas formas estão na seção Grammar Notes (Notas de Gramática), em uma tabela, que os alunos devem preencher após reler a história, com a ajuda do professor. O objetivo das seções sobre gramática é explicitar a ocorrência e frequência dessas múltiplas formas. Aqui, tirando os efeitos de diagramação, o resto se compara com uma forma de ensino em livro didático tradicional.

Na página 12, na seção Words in Action (Palavras em Ação), há apresentação de vocabulário e sugere-se que os alunos produzam um crachá com seus nomes. Para isso, o livro traz cinco passos para a elaboração do crachá. A página 13 traz a atividade 2 da seção. A instrução pede que os alunos olhem e respondam. Alunos do professor Greg aparecem, com seus respectivos crachás no peito, dizendo qual é a forma e a cor de seu crachá. No canto da página, o personagem felino Jack Lynx pede que os alunos façam o mesmo, perguntando qual a cor e a forma de seus crachás.

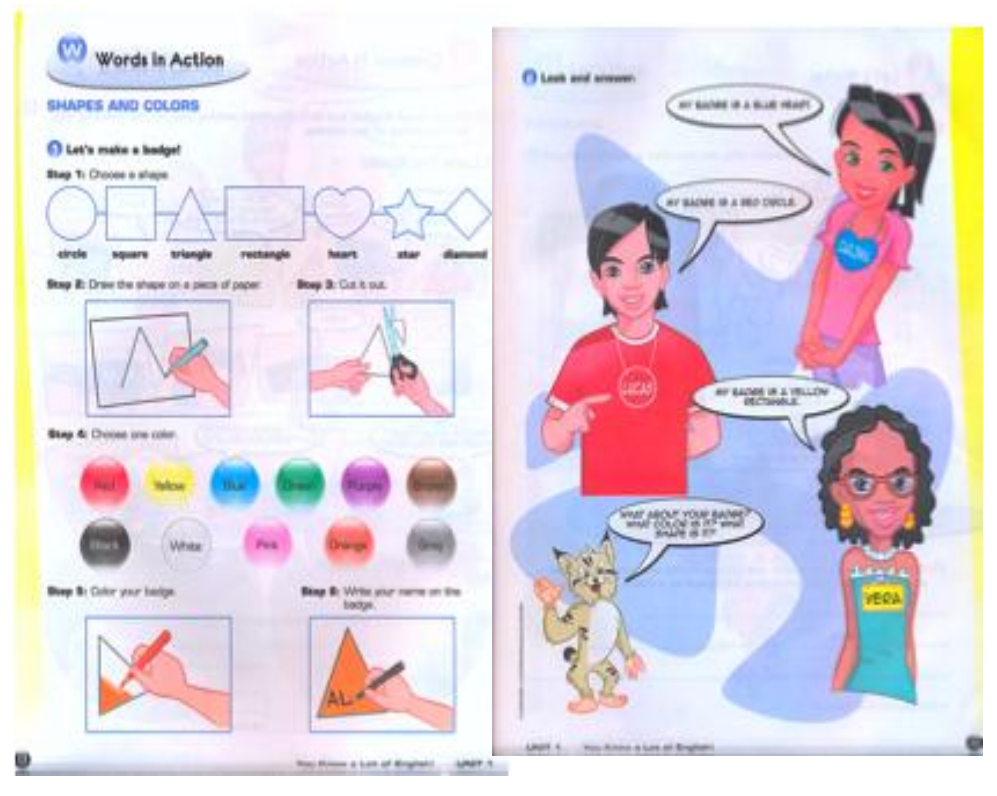

FIGURA 5 - Páginas 12 e 13

Na página 14, encontra-se a seção Let's write (Vamos escrever). A atividade 1 mostra um aluno do professor Greg apresentando um pôster com a pergunta Who am I? (Quem sou eu?), a silhueta do jogador de futebol Ronaldinho Gaúcho (identificável pelos cabelos encaracolados e uniforme de futebol) mais uma vez a alusão à mídia, na temática "celebridades", tão presente hoje na indústria cultural. 
CASA, Vol.11 n.1, julho de 2013

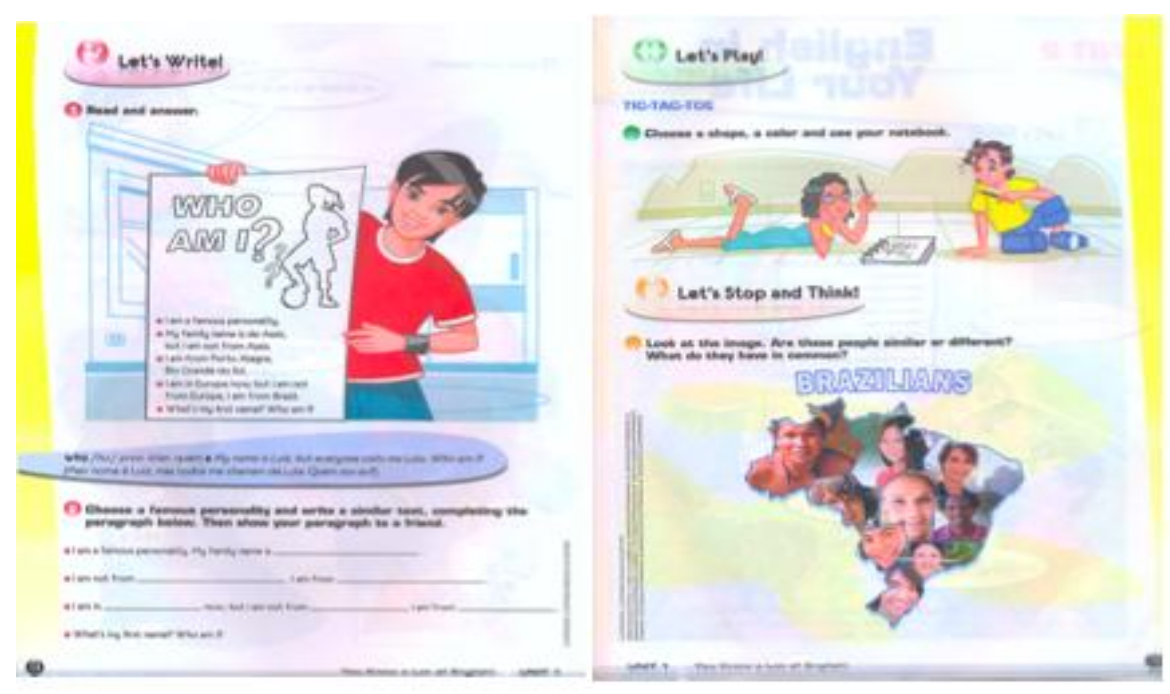

FIGURA 6 - Páginas 14 e 15

Os alunos, depois de "descobrirem" que a personalidade referida na atividade é o jogador de futebol, devem utilizar as informações ali presentes para criar um parágrafo, com pistas para seu leitor adivinhar uma personalidade famosa. Essa é a proposta da atividade 2, que solicita ao aluno que escolha uma pessoa famosa e escreva um texto similar, terminando o parágrafo que vem abaixo (as frases estão começadas). Pede-se que os alunos mostrem o que escreveram a um amigo, que deverá tentar adivinhar sobre quem escreveram em seus parágrafos.

A página 15 apresenta as duas últimas seções da unidade, Let's Play e Let's Stop and Think. Na seção Let's Play (Vamos brincar), sugere-se que os alunos escolham, em duplas, uma forma geométrica e joguem o jogo da velha no caderno. A seção traz a figura de dois alunos jogando o jogo, no chão da sala de aula.

A unidade é encerrada com a seção Let's Stop and Think, que traz um mapa do Brasil com fotos de pessoas de etnias diferentes em cada região. Acima do mapa está a palavra BRAZILIANS (brasileiros). A instrução pede que os alunos observem a imagem e respondam: essas pessoas são parecidas ou diferentes? O que elas têm em comum?

Aqui transparece a intenção de abordar a discussão sobre a temática da variedade étnica no Brasil, já presente nas páginas anteriores da unidade, na aparência dos alunos de Greg e Jane. Como os alunos de Jane são de nacionalidades diferentes, eles têm uma aparência étnica distinta. Da mesma forma, os alunos de Greg apresentam traços étnicos variados por serem brasileiros, povo de etnias diferentes. Essa temática enfatiza a ideia de que o Brasil é internacional e de que o preconceito étnico em qualquer instância é algo a ser combatido, um discurso largamente permeado pelas lógicas de mídia, difundido no Brasil pelas telenovelas e jornais.

A análise das páginas da unidade 1 do Links revela a figurativização dos temas e os efeitos de sentido produzidos nessa direção, isto é, o modo como o uso da linguagem 
sincrética constrói esse mundo tecnológico e interativo, que pressupõe a liberdade e o saber como forma de alcançá-la, conforme pressuposto na capa do material didático.

\section{CONSIDERAÇÕES}

Mediante a análise da capa e da primeira unidade de Links, notamos que, nesse material, a aula de inglês enquanto prática social é concebida como espaço de interação e da presença de temáticas emergentes na sociedade contemporânea. Porém, apesar de todo este revestimento de atualidade, a aula ainda está centrada nas figuras do professor e do próprio livro didático como sujeitos do saber, ao passo que o aluno, apesar de respeitado em seus saberes (You know a lot of English) e mais livre para efetuar escolhas, ainda é o receptor do conhecimento. Embora a internet, as novas tecnologias midiáticas e a sociedade em rede sejam frequentemente referidas, não há direcionamento a páginas da internet sobre o conteúdo nele exposto. Isto, para nós, mostrou-se paradoxal na medida em que o próprio nome do livro faz referência à hipertextualidade da linguagem usada na rede, ou seja, no livro Links faltam os links. Não são propostas atividades em rede, fora do livro didático. O grande lugar da aprendizagem continua a ser o livro e a sala de aula.

O que chama a atenção é que o livro utiliza a temática da internet, mas não estimula seu uso, não remete o aluno ao que Jenkins (2008) chamou de "cultura participativa" online da busca pela informação e construção coletiva do conhecimento (LEVY, 1998):

O professor James Paul Gee, da Escola de Educação Madison, da Universidade de Wisconsin, chama essa culturas informacionais de aprendizado de "espaços de afinidade" e questiona por que as pessoas aprendem mais, participam mais ativamente e se envolvem mais profundamente com a cultura popular do que com os conteúdos dos livros didáticos. (JENKINS, 2008, p. 236)

Pois bem, se falamos de crise na educação tradicional e vemos que ao mesmo tempo há um aumento na busca dos jovens pelas "culturas informacionais" das quais a internet é elemento nuclear, não poderia estar aí o ponto da ruptura? Em uma sociedade em processo de midiatização, em que os sujeitos são expostos a todo momento pelos dispositivos midiáticos, as disputas de sentidos nos diversos campos sociais, inclusive a educação, parecem menos inteligíveis fora das lógicas de mídia.

O uso do temática web e a constante abordagem do assunto na unidade estudada demostram que os autores do livro sabem da "força simbólica" que isso denota, mas a utilização parece ficar no campo de uma realidade externa ao ensino/aprendizagem como um lugar místico, inacessível enquanto práxis de educação. O que denota certa contradição, pois o livro é distribuído pelo PNLD e o governo também possui um Programa de Inclusão Digital, ${ }^{6}$ no qual se inclui o ProInfo (Programa Nacional de Informática na Educação). Não que inclusão digital seja sinônimo de inclusão social, mas apenas pontuamos a questão para demonstrar que não haveria uma incompatibilidade na política de educação do estado, antes, o próprio governo entendeu o que alerta Castells (2003, p. 8): "De fato, ser excluído dessas redes é sofrer uma das formas mais danosas de exclusão em nossa economia e em nossa cultura."

\footnotetext{
${ }^{6}$ Disponível em: http://www.inclusaodigital.gov.br
} 
Por outro lado, possivelmente, essa escolha de deixar a internet de fora das proposições pedagógico-metodológicas do livro pode dever-se ao fato de que ainda não há consenso, nem no ambiente acadêmico, nem no escolar, de que a aplicação de propostas de aprendizagem na rede mundial de computadores seja profícua, uma vez que ela enseja riscos, como o acesso a conteúdos de qualidade duvidosa e a possibilidade de perda do foco da proposta pedagógica pela navegação no imenso banco de dados (MANOVICH, 2001) que compõe a internet. Pode dever-se também à falta de integração das políticas públicas nacionais, à descrença na eficiência do Proinfo, ou a uma diferença de períodos entre a elaboração do livro didático e sua inserção no PNLD e o início do ProInfo, visto que este existe desde 1997, enquanto o livro didático de língua estrangeira/adicional somente foi integrado ao PNLD no ano de 2011, embora outras áreas, principalmente dos anos iniciais do Ensino Fundamental já sejam contempladas pelo Programa Nacional do Livro Didático desde 1985.

Também é questionável o fato de os personagens principais, professores de inglês, serem um americano e uma britânica em tempos em que o próprio idioma se "globaliza" e perde parte de suas marcas identitárias locais. Por que falantes nativos? Professores brasileiros de formação sólida não seriam tão ou mais eficientes como docentes do idioma a nossos estudantes de Ensino Fundamental? E por que esses personagens e seus alunos devem viver no Rio de Janeiro? Essa escolha geográfica não contribui para a estereotipia do Brasil e sua redução, tendo em vista a diversidade étnica e sociocultural e as dimensões do país?

Não há dúvida de que a nova geração da tecnologia trouxe mudanças ao modo como a aula é construída, uma vez que até mesmo no livro didático ela pretende-se interativa, composta de linguagens múltiplas (visual, verbal, sonora). De fato, é dever do pesquisador olhar para essas transformações e discuti-las, na busca por possibilitar mais autonomia para o estudante, estimulando sua "curiosidade epistemológica" (FREIRE, 1997). Nesse sentido, Paulo Freire já se alinhava à teoria semiótica ao afirmar que "o espaço pedagógico é um texto para ser constantemente lido, interpretado, escrito e reescrito.” (1997, p. 109).

\section{REFERÊNCIAS}

BAUDRILLARD, J. Simulacros e simulação. Lisboa: Relógio D’Água, 1981.

BRAGA, J. L. Dispositivos Interacionais. Artigo apresentado no Grupo de Trabalho Epistemologia da Comunicação, do XX Encontro da Compós, na UFRGS, Porto Alegre, em junho de 2011.

CASTELLS, M. A galáxia da internet: reflexões sobre a internet, os negócios e a sociedade. Trad. Maria Luiza X. de A. Borges. Rio de Janeiro: Jorge Zahar Ed., 2003.

FERREIRA, J. Midiatização: dispositivos e processos sociais de comunicação. E-Compós (Brasília), v. 10, p. 1-15, 2007.

FONTANILLE, J. Significação e visualidade: exercícios práticos. Trad. Elizabeth Bastos Duarte e Maria Lília Dias de Castro. Porto Alegre: Sulina, 2005.

FONTANILLE, J. Práticas semióticas: imanência e pertinência, eficiência e otimização. In: DINIZ, M. L. V.; PORTELA, J. Semiótica e mídia: textos, práticas, estratégias. Bauru: UNESP/FAAC, 2008.

FREIRE, P. Pedagogia da Autonomia: Saberes necessários à prática educativa. São Paulo, Brasil: Paz e Terra (Coleção Leitura), 1997.

GARCEZ, P. M. A organização da fala-em-interação na sala de aula: controle social, reprodução de conhecimento, construção conjunta de conhecimento. Calidoscópio, vol. 4 n. 
1, p. 66-80, jan/abr, 2006.

GREIMAS, A. J.; COURTÉS, J. Dicionário de semiótica. Trad. Alceu Dias Lima et al. São Paulo: Cultrix, 1983.

JENKINS, H. Cultura da convergência. Trad. Susana Alexandria. São Paulo: Aleph, 2008. ILLICH, I. Sociedade sem escolas. Ed. Vozes, Petrópolis, 1977.

LÉVY, P. A inteligência coletiva: por uma antropologia do ciberespaço. 3. ed. São Paulo: Loyola, 2000.

MANOVICH, L. The Language of New Media. London: The MIT Press Cambridge, 2001. MARQUES, A.; SANTOS, D. Links: English for Teens. V. $1,6^{\circ}$ ano. $1^{\text {a }}$ ed. São Paulo: Ática, 2009.

SILVA, J. C. da. A escola pública no Brasil: problematizando a questão. Revista Publicatio, UEPG, Ponta Grossa, Vol. 15, n. 2, 2007.

SINCLAIR J. M; COULTHARD, M. Towards an analysis of discourse. Oxford: Oxford University Press, 1975.

SOUZA JUNIOR, J. Trabalho, estado e escola: crises que se entrecruzam. Trabalho apresentado no $25^{\circ}$ Encontro da Anped, 2002. Disponível em <www.anped.org.br/reunioes/25/justinosousajuniort09.rtf>. Acesso em: 20 maio 2012. 